DOI https://doi.org/10.32837/app.v0i66.717

УДК $327(477+476)$

Р. М. Кондратенко

orcid.org/0000-0002-7982-0786

аспирант

Центра исследований безопасности

Национального института стратегических исследований

\title{
РОЛЬ ПУБЛИЧНОЙ ДИПЛОМАТИИ В УКРАИНСКО-БЕЛОРУССКИХ ОТНОШЕНИЯХ
}

На границе XX и XXI вв. в мире произошли кардинальные перемены. По мнению У. Бека (Лебедева, 2017, с. 89), эти изменения представляют собой смену политических координат. Он сравнивает современную политическую науку с открытиями Галилео в астрономии. При этом большая часть авторов связывает изменения в международной политике с крушением биполярной системы. В целом можно говорить о глобальной трехуровневой трансформации современного политического мира:

1) разрушение Вестфальской системы;

2) крах системы межгосударственных отношений;

3) изменения в политических системах современных государств.

Суть реорганизации современной политической системы заключается в одновременном протекании всех трех процессов, образующих эффект синергии путем усиления друг друга. Все эти процессы имеют прямое воздействие на публичную дипломатию, которую можно описать как политическое воздействие одного государства на другое.

Стоит отметить, что публичная дипломатия - это часть инструмента «мягкой силы», предполагающего, как считает Дж. Най, создание привлекательности государства. Согласно этой концепции идея привлекательности является новой для современных государств. Основное ее отличие от пропаганды в том, что при привлекательности для сторон характерен добровольный и осознанный выбор. При этом не стоит считать, что привлекательность не может использоваться с целью пропаганды. В случаях, когда необходимо организовать быстрое и краткосрочное воздействие, применение привлекательности в качестве пропаганды является очень эффективным.

Выделяют такие каналы воздействия при помощи публичной дипломатии:

- воздействие по официальным каналам: выступления официальных лиц, публичные лекции, посты в социальных сетях;

- воздействие по неофициальным каналам: различные образовательные программы, молодежные и женские организации, учебные заведения.

Поскольку в литературе не отражен тот факт, что существуют официальные и неофициальные каналы публичной дипломатии, то в русскоязычной литературе понятие публичной дипломатии является крайне размытым. Отсюда и целесообразность исследований, связанных с воздействием публичной дипломатии в качестве мягкого силового воздействия на межгосударственные политические процессы.

1. В конце XX - вначале XXI в. при сохранении в целом тех же политических целей в основных актеров мировой политики наблюдается качественное изменение роли и значения средств официальной и публичной дипломатии. Это соотношение начало заметно меняться еще в 60-е-70-е годы XX в., когда появились многочисленные политические и общественные организации, а также СМИ, чье влияние стало стремительно усиливаться, нередко в ущерб политико-дипломатическим средствам официальной дипломатии. Рубежом, наверное, стало подписание Заключительного акта в Хельсинки в августе 1975 года, которое фактически легализовало общественные организации в качестве политических инструментов, государств и отдельных актеров. Особенно быстро этот процесс пошел после появления вначале XXI в. электронных СМИ и социальных сетей (Циватый, 2017, 43-44). 
В современном мире публичная дипломатия пользуется особым интересом, является одним из атрибутов международной жизни. Страны ЕАЭС также проявляют повышенный интерес к публичной дипломатии, поскольку необходимость построения благоприятного международного имиджа государства является сегодня одной из наиболее актуальных и важных задач, а формирование у зарубежной аудитории положительных взглядов на проводимую государством внешнюю и внутреннюю политику относится к сфере публичной дипломатии (Лебедева, 2015).

Однако вопрос о ресурсах публичной дипломатии до сих пор открыт. Это связано с тем, что объединения постсоветских государств не делятся опытом применения этих ресурсов в контексте интеграционного сотрудничества. Таким образом, актуальность проблемы ресурсов публичной дипломатии является очевидной, а использование и усовершенствование ее механизмов нуждается в глубоком изучении.

Проведем анализ межгосударственных соглашений между Республикой Беларусь и Украиной и возможные перспективы влияния публичной дипломатии на усиление и расширение их взаимного влияния. 17 декабря 1991 года между Республикой Беларусь и Украиной были установлены дипломатические отношения, через которые оба государства стремятся к взаимовыгодному сотрудничеству. Важность этих отношений обусловлена историко-культурной и географической близостью.

Стоит заметить, что политическое сотрудничество между Украиной и Беларусью развивается не так стремительно, как экономическое. В 1993 году в Киеве было открыто белорусское посольство. 27 декабря 2016 года дипломатическим отношениям между Беларусью и Украиной исполнилось 25 лет. Безусловно, за эти почти 27 лет накоплен потенциал, который способен перевести эти отношения в стратегическое партнерство, в первую очередь в сфере экономики.

Политические процессы и дипломатия XXI в. являются главным трендом в глобализации современного мира и общества. Институциональным вектором в этом направлении является именно экономическая дипломатия, являющаяся важнейшим инструментом дипломатической и внешнеполитической деятельности Украины и Республики Беларусь (Украинскобелорусские отношения: история, настоящее, перспективы, 2020). В последнее время (а именно 5-6 лет) на повестке дня появился миротворческий вектор в политике и дипломатии Республики Беларусь. Но в первую очередь его задачей является защита собственных экономических интересов.

На 2016 год прогнозировался кризис в военно-политических регионах Украины, что заставило Беларусь искать новые рынки сбыта, поскольку для ее экспортно-ориентированной экономики такой прогноз не предвещал ничего хорошего. Власти Республики Беларусь вынуждены были принимать политико-дипломатические отношения для устранения экономических дисбалансов и компенсации потерь на рынках сбыта, привлекать новых инвесторов в белорусскую экономику, внедрять современные технологии.

2. Стоит обратить внимание на тот факт, что за последние 20 лет у Республики Беларусь возникали различные проблемы и трудности, связанные с особенностями внешней политики. Соседи Беларуси считали, что Минск имеет такие же приоритеты внешней политики и дипломатии как Киев, Берлин, Москва, Париж, Варшава, Лондон, Вашингтон (Лазоркина, 2014 , с. 27-32). В результате этого защита Беларусью своих экономических интересов в дипломатическом и внешнеполитическом планах рядом стран трактуется совершенно неверно. Они считают, что Республика Беларусь проявляет амбиции на региональное лидерство, желает бросить вызов соседним государствам, не думая о последствиях.

Важно правильно понимать особенности внешней политики и дипломатии Беларуси. Поскольку правильное понимание является ключом к толерантным, ровным, спокойным и сбалансированным политико-дипломатическим отношениям. Стоит отметить, что за почти 27 лет политико-дипломатических отношений Республики Беларусь и Украины состоялось порядка 90 официальных двухсторонних встреч. За все время этих отношений президент Республики Беларусь и все президенты Украины неизменно доказывают, насколько важны белорусско-украинские отношения.

Оба государства имеют схожие взгляды на создание новой архитектуры безопасности с обязательным предоставлением гарантий безопасности безъядерным государствам. 
Они считают, что принципы открытого общества должны быть основой международной политической архитектуры. Сутью открытого политического общества является признание недоступности абсолютной истины. Поэтому для мира во всем мире мировому сообществу и всем государствам необходимо использовать средства и политико-дипломатический инструментарий для успешного сотрудничества, уважать интересы и точки зрения других государств.

Глобальное мышление должно стать ключом к глобальной дипломатии, задачей которой является обеспечение мира на планете. Таким образом, произойдет переход глобальной дипломатии в планетарную. Политико-дипломатический диалог и дипломатия должны стать средством решения глобальных политических и межгосударственных проблем современного мира.

Существование публичной дипломатии вне социальных рамок, вне конкретного общества национального государства является не возможным. В условиях глобального пространства современная публичная дипломатия использует накопившийся исторический опыт: методы и формы дипломатии, принципы организации и ведения внешней политики. Обеспечение устойчивого экономического развития и внутриполитической стабильности государств в дипломатических системах современного мира является наиболее главной задачей внешнеполитических служб.

Современная дипломатия Республики Беларусь пребывает на службе суверенной Беларуси. В дипломатической модели Беларуси подчеркнуты жизненность и динамичность ее внешней политики и дипломатии. Укрепление стратегического партнерства на пространстве СНГ является приоритетным направлением политики Беларуси (Беларусь и Украина будут создавать новые совместные предприятия, 2009).

В Республике Беларусь создан прочный фундамент социального государства за годы ее независимости. Уровень социального развития вплотную приблизился к уровню среднеевропейских стран. Неуклонно растут стандарты жизни жителей государства. Благодаря инновационному и постиндустриальному развитию в Беларуси происходит общественно-политическая модернизация, созданы основы гражданского общества.

Переходу к новому технологическому укладу и увеличению экономической конкурентоспособности Республики Беларусь способствуют всестороннее развитие науки и коммерциализация технологий. Для Беларуси очень важно, чтобы в процессе политико-экономической, политико-дипломатической и институциональной модернизации был найден оптимальный баланс между экономическими успехами и обеспечением общественных благ. Немаловажным является факт дружеских и доброжелательных двухсторонних внешнеполитических и дипломатических отношений между Беларусью и Украиной.

Участие Республики Беларусь и Украины всегда идет в тесном межгосударственном тандеме как в мировой политике и международном сотрудничестве, так в различных институциональных и интеграционных объединениях современного полицентричного мира. Важную роль в укреплении и развитии партнерства Республики Беларусь и Украины традиционно играют встречи на высоком уровне и переговоры, которые способствуют укреплению политического, экономического и культурно-гуманитарного сотрудничества двух государств. На сегодня оба государства взаимно заинтересованы в развитии двустороннего экономико-торгового сотрудничества.

Успешному экономическому сотрудничеству Беларуси и Украины способствует их географическая близость и взаимная заинтересованность в производимой продукции. Ежегодно происходит рост товарооборота между двумя государствами. В Беларуси основой экспорта является машиностроительная продукция и продукция химической промышленности, в Украине продукция пищевой, металлургической и химической промышленности, электроэнергия.

На территории Украины имеются совместные предприятия: ООО «БНК Украина», ООО «Украинский торговый дом «Белшина», ООО «БНХ Украина», ООО «Промагролизинг-Украина», ООО «ТД МАЗ-Украина», ООО «ДОНБАСС-БЕЛАЗ-СЕРВИС», ООО «Карат-Лифтокомплект», АОЗТ «Атлант-Украина», ООО Торговая компания «Милавица», ООО «Торговый дом «Оршанский льнокомбинат-Одесса», ООО «Беллакт-Украина», ТОО «Торговый дом «Бабушкина крынка Украина», ООО ТД «Гомельстекло-Украина» и другие (Беларусь и Украина: двухсторонние отношения, 2015). 
Украина является вторым по совокупному объему торговым партнером Беларуси и третьим по уровню белорусского экспорта. В то время как Беларусь является только пятым торговым партнером для Украины. Стоит отметить, что Республика Беларусь и Украина заключили между собой порядка 212 международных двухсторонних договоров. Основными являются:

- «Договор о дружбе, добрососедстве и сотрудничестве», заключенный в 1995 году;

- «Соглашение о свободной торговле», которое было заключено в 1992 году и изменено в 2006 году;

- «Договор о государственной границе между Украиной и Республикой Беларусь», подписанный в мае 1997 года, ратифицированный Украиной в июле 1997 года и Республикой Беларусь в апреле 2010 года.

В 2017 году были проведены три встречи глав Республики Беларусь и Украины. Эти встречи показали практическую заинтересованность в укреплении экономических и политических отношений между двумя государствами. В апреле 2017 года главы государств провели переговоры в н.п. Лясковичи (Республика Беларусь) и на Чернобыльской АЭС. В июле 2017 года Президентом Беларуси Александр Лукашенко был совершен официальный визит в Украину (Беларусь и Украина: двухсторонние отношения, 2015). Также в июле 2017 года состоялся 1 Белорусско-украинский экономический бизнес-форум, на котором присутствовало более 500 делегатов от двух государств. На форуме был подписан ряд двухсторонних документов и контрактов, проведена контактно-кооперационная биржа.

19 июля 2017 года в Киеве прошло 25 заседание Межправительственной белорусской-украинской смешанной комиссии по вопросам торгово-экономического сотрудничества. Руководили заседанием заместитель Премьер-министра Республики Беларусь Владимир Семашко и Вице-премьер-министр Министр регионального развития, строительства и жилищно-коммунального хозяйства Украины Геннадий Зубко. В ноябре 2017 года в ходе рабочей встречи Александра Лукашенко и Петра Порошенко в Объединенных Арабских Эмиратах были рассмотрены имеющиеся двухсторонние вопросы и направления развития публичной дипломатии между Украиной и Республикой Беларусь.

В условиях экономического кризиса и глобализации, а также вследствие конфликта на Донбассе, что сказывается на товарообороте и показателях торговли, правительствам следует отойти от протекционистской политики и отказаться от «торговых войн» как средства решения спорных экономических вопросов. Одним из важнейших вопросов на повестке дня международных отношений в целом и внешней политики Республики Беларусь в частности вот уже столь длительное время является вопрос урегулирования ситуации в Украине и вокруг нее в геополитическом пространстве международно-политического региона. Республика Беларусь заинтересована в благополучии Украины. Именно поэтому Минск является площадкой урегулирования конфликта на Донбассе. В июне 2017 года в Беларусь совместно с Международным комитетом Красного Креста доставила в Украину гуманитарную помощь для граждан, которые находятся в зоне конфликта.

3. В августе 2017 года было организовано оздоровление и отдых для украинских детей из семей военных и малообеспеченных семей, проживающих в Донецкой и Луганской областях (Мазина, 2012, с. 192).

Отдельно стоит рассмотреть отношения Республики Беларусь и Украины в области культуры, которые регулируются Протоколом между Министерством культуры Республики Беларусь и Министерством культуры Украины «О сотрудничестве в области культуры и искусства» от 16 июня 2003 года, Соглашением между правительством Республики Беларусь и Кабинетом Министров Украины «О сотрудничестве в области охраны историко-культурного наследия» от 29 апреля 2010 года и Программой сотрудничества между Министерством культуры Республики Беларусь и Министерством культуры и туризма Украины на 2017-2021 годы.

Программа сотрудничества предусматривает двухсторонний обмен самодеятельными и музыкальными коллективами, развитие и налаживание контактов между учреждениями культуры. В рамках Программы сотрудничества за 2010-2013 годы в Киеве в октябре 2011 года состоялась церемония торжественного открытия памятника Владимиру Короткевичу. В церемонии приняли участие министры культуры Украины и Беларуси. 
Международный фестиваль искусств «Славянский базар в Витебске» является приоритетным совместным проектом двух государств. На фестиваль ежегодно приглашаются мастера искусств и художественные коллективы Украины, официальные лица.

Представители Украины ежегодно представляют свою страну на множестве проводимых в Беларуси фестивалей (Международный фестиваль искусств «Белорусская музыкальная осень», Минский международный кинофестиваль «Листопад»). Белорусские коллективы также участвуют в украинских фестивалях и мероприятиях (Беларусь и Украина обсудили перспективы двухстороннего научно-технического сотрудничества и двухсторонние отношения, 2020).

В июне 2017 года в Николаевской области Украины состоялись Дни культуры Республики Беларусь. Между национальными библиотеками Беларуси и Украины также налажено тесное сотрудничество, осуществляется книгообмен, формируются общие информационные ресурсы. В октябре 2017 года в рамках празднования 500-летия белорусского книгопечатания в торжественной обстановке в Национальной библиотеке имени В.И. Вернадского руководством Национальной библиотеки Республики Беларусь было презентовано и передано полное факсимильное издание книжного наследия Ф. Скорины.

В декабре 2017 года руководством Национальной библиотеки Республики Беларусь в Киеве было передано в дар Государственному музею книги и книгопечатания Украины, Национальной научной библиотеке имени Я. Мудрого, Государственному историко-культурному заповеднику г. Острога, Харьковской государственной научной библиотеке имени В.Г. Короленко, Одесской национальной научной библиотеке, Закарпатскому областному краеведческому музею имени Т. Легоцкого, Национальному музею во Львове имени А. Шептицкого и Национальной научной библиотеке имени В. Стефаныка издание «Книжное наследие Франциска Скорины».

В гуманитарной сфере также происходит укрепление взаимоотношений. Так, в мае 2017 года была подписана Программа сотрудничества в сфере физической культуры и спорта на 2017-2018 года, в рамках которой созданы все условия для эффективной работы в сфере спорта и туризма. В июле 2017 года в ходе визита на высшем уровне было подписано Соглашение о сотрудничестве в сфере межнациональных отношений.

Что касается сотрудничества в научно-технической области, то основополагающим документом является межправительственный договор «О сотрудничестве в области науки и технологий» от 1992 года. За реализацию этого договора отвечают Государственный комитет по науке и технологиям Республики Беларусь и Министерство образования и науки, молодежи и спорта Украины (Договор между Российской Федерацией и Республикой Беларусь о создании Союзного государства, 1999). В целях успешной реализации этого Договора была создана белорусско-украинская Межправительственная комиссия по сотрудничеству в области науки и технологий, которая приняла Программу научно-технического и инновационного сотрудничества до 2020 года.

Между Беларусью и Украиной действует Рамочное межправительственное соглашение о сотрудничестве в области исследования и использования космического пространства в мирных целях. Утверждены Направления перспективного сотрудничества предприятий и организаций Республики Беларусь и Украины в космической сфере. Стоит отметить, что фондами фундаментальных исследований осуществляется самое активное межгосударственное сотрудничество между Украиной и Беларусью. Ежегодно в рамках различных совместных белорусско-украинских проектов проводятся различные конкурсы научных и научно-практических работ.

На сегодня в Беларуси действуют 16 общественных организаций украинцев, 13 из которых зарегистрированы органами юстиции Беларуси, 8 из них входят в Республиканское Белорусское общественное объединение украинцев (БООУ) «Ватра», три являются членами Украинского Всемирного Координационного Совета (Минское городское культурно-просветительское общество «Центр украинской культуры «Сич», Гродненское городское культурно-просветительское общество «Барвинок» и Украинский научно-педагогический союз «Берегиня»). Таким образом, Украина и Республика Беларусь имеют все необходимые условия для перехода на качественно новый этап межгосударственного сотрудничества - партнерства с перспективой на переход в стратегическое партнерство. 
Современная модель дипломатии Республики Беларусь заслуживает на высокую оценку и неизбежно требует ее дальнейшего изучения в исторической ретроспективе и перспективе. Опыт дипломатии Беларуси представляет интерес для других государств. Республика Беларусь является инициатором дальнейшего развития многопланового сотрудничества с Украиной. Вместе с тем, учитывая геополитическую ситуацию в регионе, отношения между Минском и Киевом можно охарактеризовать как сложные с точки зрения выстраивания отношений по линии официальной дипломатии.

Республика Беларусь пребывает в глубоких интеграционных процессах с РФ, которые, согласно подписанному 8 декабря 1999 года в Москве Договору о создании Союзного государства между РФ и РБ, предусматривают поэтапную организацию единого политического, экономического, военного, таможенного, валютного, юридического, гуманитарного и культурного пространства («Світова гібридна війна: український фронт», 2020). Кроме того, Беларусь является постоянным членом ОДКБ.

Следует отметить, что на Беларусь осуществляется влияние с использованием как экономических, так и военных рычагов. Как член Союзного государства РБ согласовывает с РФ внешнюю политику, вопросы обороны, безопасности, бюджета, денежно-кредитной и налоговой системы, энергетики, транспорта и связи, а также таможенную политику. Таким образом Россия имеет возможность влиять на принятие решений по ключевым вопросам внешней и внутренней политики Беларуси (Программа трансграничного сотрудничества (ТГС) «Польша-Беларусь-Украина», 2020). Эти факторы заставляют украинскую дипломатию маневрировать на белорусском направлении с каждым новым витком обострения отношений между Москвой и Киевом.

В сложившейся ситуации на первый план в налаживании добрососедских отношений между государствами, имеющими 1084 км общей границы, выходит публичная дипломатия, не ограниченная протокольными рамками и идущая параллельным курсом с официальной линией внешнеполитического ведомства. Публичная дипломатия способствует укреплению взаимоотношений на уровне гражданского общества, прокладывая путь официальной. Ярким примером публичной дипломатии в действии служит реализация совместных проектов международной технической помощи Европейского Союза в рамках «Программы трансграничного сотрудничества Польша-Беларусь-Украина», которая на протяжении 15 лет поддерживает процессы трансграничного развития в приграничных районах Польши, Беларуси и Украины по средствам софинансирования разносторонних проектов.

Все проекты, финансируемые в рамках программы «Польша-Беларусь-Украина» (далее Программа), являются некоммерческими и вносят вклад в улучшение качества жизни жителей восточной Польши, западной Украины и Беларуси. Каждая инициатива, финансируемая программой, демонстрирует ярко выраженный трансграничный эффект не только через налаженное партнерство между организациями из этих трех стран, но и за счет достигнутых результатов проектов и позитивного влияния на приграничную территорию. Финансирование направлено на защиту и продвижение культурного и природного наследия приграничных регионов, инфраструктурную доступность регионов, улучшение инфраструктуры пограничных пунктов пропуска, процедур и услуг, которые там оказываются, равно как и развитие здравоохранения и служб защиты населения.

Следует отметить, что за 15 лет существования Программы были успешно реализованы сотни проектов при участии как органов государственной власти и местного самоуправления, так и огромного количества общественных организаций и объединений Польши, Беларуси и Украины. Необходимо также подчеркнуть независимость инструмента публичной дипломатии от существующих в регионе геополитических вызовов, ее эффективность в социальной, культурной и гуманитарной сферах (Программа трансграничного сотрудничества (ТГС) «Польша-Беларусь-Украина», 2020).

Согласно данных, предоставленных Совместным техническим секретариатом Программы (СТC), который является органом администрирования, за программный период 2007-2013 лет в рамках Грантовых контрактов софинансирования ЕС были распределены по приоритетам:

Приоритет 1 - заключено 40 проектов на сумму 55143 537,52 евро;

Приоритет 2 - заключено 26 проектов на сумму 76941 106,16 евро; 
Приоритет 3 - заключен 51 проект на сумму 42302 390,85 евро.

Из 117 проектов 14 были реализованы в рамках польско-белорусско-украинского партнерства, 74 проекта - в польско-украинском партнерстве, 29 - в польско-белорусском партнерстве.

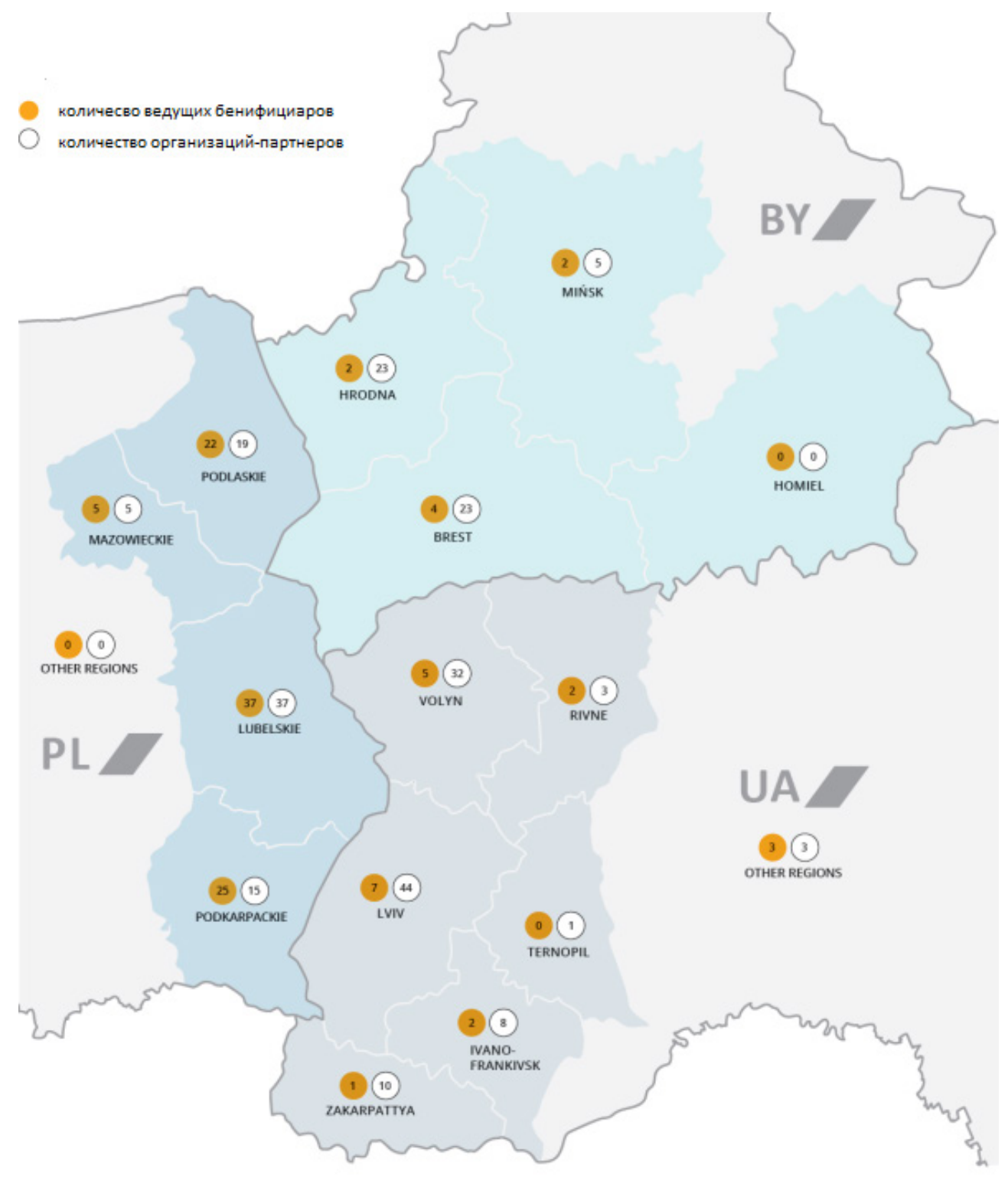

В рамках 117 проектов, реализованных в рамках Программы, были достигнуты такие результаты:

- создано 467 новых рабочих мест (после окончания проекта);

- создано 12 организаций по развитию бизнеса;

- 1014 предпринимателей / компаний, обслуживаемых в рамках проекта;

- 453 новых предпринимателя / компании, зарегистрированных благодаря поддержке в рамках проекта;

- 52 улучшенных культурно-исторических объекта;

- создано 31 туристический информационный центр / пункт;

- 1875 км построенных / маркированных / обозначенных туристических маршрутов / велосипедных маршрутов / водных маршрутов;

- построено / реконструировано 10 пограничных переходов;

- 29865 автомобилей в день: было увеличено пропускные способности границы;

- 48800 человек в день: были увеличены пропускные способности границы; 
- 1729 трансграничных встреч / конференций. Рабочие группы / тренинги / семинары;

- 53527 участников трансграничных встреч / конференций / рабочих групп / тренингов / семинаров;

- 751 фестиваль / спортивные мероприятия / другие публичные мероприятия;

- 186 совместных научных исследований;

- 71 модернизированный корпус;

- $\quad$ 116,5 км - длина вновь построенных или реконструированных дорог;

- приобретено 246 автомобилей (милиция, пожарные, медицинские);

- 349 комплектов аварийного оборудования (например, полиция, пожарные команды, техника для обслуживания дорог);

- 2365 домашних хозяйств / общественных зданий, подключенных к построенным / модернизированным системам водоснабжения;

- 5 построенных / модернизированных очистных сооружений;

- 90,8 км построенной / модернизированной канализации;

- 750 пациентов медицинских осмотров / анализов / лечения;

- 1048 комплектов медицинского оборудования;

- 24 инициативы, организованные для инвалидов.

Анализ результатов взаимодействия в рамках Программы трансграничного сотрудничества «Польша-Беларусь-Украина 2007-2013» свидетельствует о ее высокой эффективности в контексте развития приграничных регионов: возведение и модернизация крупных инфраструктурных проектов, улучшение климата для бизнеса с последующим привлечением инвестиций, улучшение качества медицинских услуг для населения, повышение туристической привлекательности.

Эффективное взаимодействие между государственными органами и органами местного самоуправления, общественными организациями и объединениями трех стран можно считать результатом действия публичной дипломатии - диалога, существующего и развивающегося за рамками официальной дипломатии и протокола (Світова гібридна війна: український фронт, 2020).

Таким образом, публичная дипломатия является неотъемлемым вспомогательным инструментом реализации внешней политики как Украины, так и Беларуси. Вопросу развития добрососедских отношений путем углубления культурных связей на уровне гражданского общества безусловно необходимо уделять больше внимания с учетом существующих вызовов безопасности в регионе. Публичная дипломатия как инструмент в ближайшей перспективе должна стать локомотивом в решении проблемных аспектов взаимоотношений двух государств, а усовершенствование ее механизмов на примере украинско-белорусских отношений должно стать предметом изучения политологии.

\section{Литература}

Лебедева М.М. Публичная дипломатия: теория и практика : научное издание. Москва : Издательство «Аспект Пресс», 2017. 272 с.

Лебедева О. Особенности института публичной дипломатии в России. Международная жизнъ. 2015. URL: https://interaffairs.ru/jauthor/material/1315.

Циватый В.Г. Республика Беларусь-Украина: 25 лет двухсторонних дипломатических отношений. 2017. C. $43-44$.

Украинско-белорусские отношения: история, настоящее, перспективы. Информационно-новостной порmaл. URL: http://dc-summit.info/temy/vneshnjaja-politika/2549-ukraino-belorusskie-otnoshenija-istorijanastojaschee-perspektivy.html.

Лазоркина О.И. Становление и развитие дипломатической службы Беларуси. Журнал международного права и международных отношений. 2014. № 1. С. 27-32.

Беларусь и Украина будут создавать новые совместные предприятия. Информационно-новостной портал «Белорусские новости». 12.06.2009. URL: https://naviny.by/rubrics/economic/2009/06/12/ic_ news_113_312861 (дата обращения: 30.10.2020).

Беларусь и Украина: двухсторонние отношения. Посольство Республики Беларусь в Украине. URL: http://ukraine.mfa.gov.by/ru/bilateral_relations.

Мазина М.Н. Белорусско-украинские культурные отношения на современном этапе. С. 191-192. 
Беларусь и Украина обсудили перспективы двухстороннего научно-технического сотрудничества и двухсторонние отношения. Государственный комитет по науке и технологиям Республики Беларусь. Режим доступа: http://www.gknt.gov.by/news/2016/belarus_i_ukraina_obsudili_perspektivy_ dvustoronnego_nauchno_tekhnicheskogo_sotrudnichestva (дата обращения: 30.10.2020).

Договор между Российской Федерацией и Республикой Беларусь о создании Союзного государства от 08 декабря 1999 года. Официальный сайт Постоянного Комитета Союзного государства. URL: https://www.postkomsg.com/documentation (дата обращения: 30.10.2020).

«Світова гібридна війна: український фронт». Монографія. Національний інститут стратегічних досліджень. URL: http:/ / www.niss.gov.ua/articles/2431.p.6.3 (дата звернення: 17.06.2020).

Программа трансграничного сотрудничества (ТГС) «Польша-Беларусь-Украина». Официальный сайт Программы. URL: https:// www.pbu2020.eu/by/pages/135.

Программа трансграничного сотрудничества (ТГС) «Польша-Беларусь-Украина». Официальный сайт Программы. URL: https:/ / www.pbu2020.eu (дата обращения: 30.10.2020).

\section{References}

Lebedeva M.M. (2017) Publichnaja diplomatija: Teorija i praktika: Nauchnoe izdanie [Public Diplomacy: Theory and Practice: Scientific Publication] / Ed. by M.M. Lebedeva: Aspect PressPublishing House, Moscow, 272 p.

Lebedeva O. (2015) Osobennosti instituta publichnoj diplomatii v Rossii [Features of the Institute of Public Diplomacy in Russia]. The International Affairs. URL: https://interaffairs.ru/jauthor/material/1315.

Tsivaty V.G. (2017) Republic of Belarus-Ukraine: Twenty-FiveYears of Bilateral Diplomatic Relations, $43-44$.

Respublika Belarus-Ukraina: dvadcat pjat let dvuhstoronnih diplomaticheskih otnoshenij [Ukraine-Belarus Relations: History, Present, Prospects]. Information and News Portal. http:/ / dc-summit.info/temy/vneshnjajapolitika/2549-ukraino-belorusskie-otnoshenija-istorija-nastojaschee-perspektivy.html.

Lazorkina O.I. (2014) Stanovlenie i razvitie diplomaticheskoj sluzhby Belarusi [Formation and Development of the Diplomatic Service of Belarus]. Journal of International Law and International Relations, 1, 27-32.

Belarus i Ukraina budut sozdavat novye sovmestnye predprijatija. Informacionno-novostnoj portal "Belorusskie Novosti". [Belarus and Ukraine will Create New Joint Ventures]. Belarus News Information and News Portal. URL: https://naviny.by/rubrics/economic/2009/06/12/ic_news_113_312861.

Belarus i Ukraina: dvuhstoronnie otnoshenija. Posolstvo Respubliki Belarus v Ukraine [Belarus and Ukraine: Bilateral Relations. Embassy of the Republic of Belarus in Ukraine]. URL: http://ukraine.mfa.gov.by/ru/ bilateral_relations (Last accessed: 17.03.2015).

Mazina M.N. (2020). Belarus-Ukraine Cultural Relations at the Present Stage. URL: https://elib.bsu.by/ bitstream/123456789/20318/1/Мазина_Украинско-экономические\% 20отношения.pdf\% 20(Last\%20 accessed:\% 2017.03.2020).

Belarus and Ukraine Discussed the Prospects for Bilateral Scientific and Technical Cooperation, Bilateral Relations. State Committee on Science and Technology of the Republic of Belarus. URL: http://www.gknt.gov. by/news/2016/belarus_i_ukraina_obsudili_perspektivy_dvustoronnego_nauchno_tekhnicheskogo_ sotrudnichestva (Last accessed: 17.03.2020).

Treaty between the Russian Federation and the Republic of Belarus on the Creation of the Union State dated December 8, 1999. Official Website of the Standing Committee of the Union State. URL: https://www.postkomsg. com/documentation (Last accessed: 17.03.2020).

The World Hybrid War: Ukrainian Forefront: Monograph. National Institute for Strategic Studies. URL: http:/ / www.niss.gov.ua/articles/2431.p.6.3 (Last accessed: 17.03.2020).

Cross-border Cooperation (CBC) Programme Poland-Belarus-Ukraine. Official website of the Programme. URL: https:/ / www.pbu2020.eu/by/pages/135 (Last accessed: 17.03.2020).

Cross-border Cooperation (CBC) Programme Poland-Belarus-Ukraine. Official site of the Programme. URL: https:/ / www.pbu2020.eu (Last accessed: 17.03.2020).

\section{Аннотация}

Кондратенко Р. М. Роль публичной дипломатии в украинско-белорусских отношениях. - Статья.

В этой статье рассматриваются вопросы роли публичной дипломатии в украинско-белорусских отношениях. Эффективное взаимодействие между государственными органами и органами местного самоуправления, общественными организациями и объединениями трех стран можно считать результатом действия публичной дипломатии - диалога, существующего и развивающегося за рамками официальной дипломатии и протокола. Существование публичной дипломатии вне социальных рамок, вне конкретного общества национального государства является невозможным.

В дипломатической модели Беларуси подчеркнуты жизненность и динамичность ее внешней политики и дипломатии. Укрепление стратегического партнерства на пространстве СНГ является 
приоритетным направлением политики Беларуси. Немаловажным является факт дружеских и доброжелательных двухсторонних внешнеполитических и дипломатических отношений между Беларусью и Украиной. Важную роль в укреплении и развитии партнерства Республики Беларусь и Украины традиционно играют встречи на высоком уровне и переговоры, которые способствуют укреплению политического, экономического и культурно-гуманитарного сотрудничества двух государств. Украина и Республика Беларусь имеют все необходимые условия для перехода на качественно новый этап межгосударственного сотрудничества - партнерства с перспективой на переход в стратегическое партнерство. Ярким примером публичной дипломатии в действии служит реализация совместных проектов международной технической помощи Европейского Союза в рамках «Программы трансграничного сотрудничества Польша-Беларусь-Украина».

Таким образом, публичная дипломатия является неотъемлемым вспомогательным инструментом реализации внешней политики как Украины, так и Беларуси. Вопросу развития добрососедских отношений путем углубления культурных связей на уровне гражданского общества безусловно необходимо уделять больше внимания с учетом существующих вызовов безопасности в регионе. Публичная дипломатия как инструмент в ближайшей перспективе должна стать локомотивом в решении проблемных аспектов взаимоотношений двух государств, а усовершенствование ее механизмов на примере украинско-белорусских отношений должно стать предметом изучения политологии.

Ключевые слова: публичная дипломатия, украинско-белорусские отношения, стратегическое партнерство, внешняя политика.

\section{Анотаиія}

Кондратенко Р. М. Роль публічної дипломатії в українсько-білоруських відносинах. - Стаття.

У статті розглядаються питання ролі публічної дипломатії в українсько-білоруських відносинах. Організацію ефективної взаємодії між державними органами і органами місцевого самоврядування, громадськими організаціями та об'єднаннями трьох країн можна вважати результатом дії публічної дипломатії - діалогу, який існує і розвивається за рамками офіційної дипломатії і протоколу. Існування публічної дипломатії поза соціальними рамками, поза конкретним суспільством національної держави є неможливим.

У дипломатичній моделі Білорусі підкреслені життєвість і динамічність тї зовнішньої політики і дипломатії. Зміцнення стратегічного партнерства на просторі СНД є пріоритетним напрямом політики Білорусі. Важливим є факт дружніх і доброзичливих двосторонніх зовнішньополітичних і дипломатичних відносин між Україною та Республікою Білорусь. Важливу роль у зміцненні та розвитку партнерства Республіки Білорусь і України традиційно відіграють зустрічі на високому рівні і переговори, які сприяють зміцненню політичного, економічного і культурно-гуманітарного співробітництва двох держав.

Україна і Республіка Білорусь мають усі необхідні умови для переходу на якісно новий етап міждержавного співробітництва - партнерства, з перспективою на перехід у стратегічне партнерство. Яскравим прикладом публічної дипломатії в дії є реалізація спільних проектів міжнародної технічної допомоги Європейського Союзу в рамках «Програми транскордонного співробітництва Польща-Білорусь-Україна». Таким чином, публічна дипломатія є невід'ємним допоміжним інструментом реалізації зовнішньої політики як України, так і Білорусі.

Питанню розвитку добросусідських відносин шляхом поглиблення культурних зв'язків на рівні громадянського суспільства безумовно необхідно приділяти більше уваги з урахуванням існуючих викликів безпеки в регіоні. Публічна дипломатія як інструмент у найближчій перспективі повинна стати локомотивом у вирішенні проблемних аспектів взаємовідносин двох держав, а вдосконалення ऑї механізмів на прикладі українсько-білоруських відносин має стати предметом вивчення політології.

Ключові слова: публічна дипломатія, українсько-білоруські відносини, стратегічне партнерство, зовнішня політика.

\section{Summary}

Kondratenko R. M. The role of public diplomacy in Ukrainian-Belarusian relations. - Article.

This article examines the role of public diplomacy in the Ukraine-Belarus relations. Effective interaction between state bodies and local self-government bodies, public organizations and associations of the three countries can be considered the result of the activity of public diplomacy - a dialogue that exists and develops outside official diplomacy and protocol. The existence of public diplomacy outside the social framework, outside a particular society of the nationstate is impossible. The diplomatic model of Belarus underlines the vitality and dynamism of its foreign policy and diplomacy.

Strengthening the strategic partnership in the CIS space is a priority area of the policy of Belarus. The fact of friendly and benevolent bilateral foreign policy and diplomatic relations between Belarus and Ukraine is also important. High-level meetings and negotiations traditionally play an important role in strengthening 
and developing partnership between the Republic of Belarus and Ukraine, which contribute to strengthening political, economic, cultural and humanitarian cooperation between the two states.

Ukraine and the Republic of Belarus have all the necessary conditions for the transition to a qualitatively new stage of interstate cooperation - partnership, with the prospect of transition into a strategic partnership. A striking example of public diplomacy in action is the implementation of joint projects of international technical assistance of the European Union within the framework of the Cross-Border Cooperation Programme Poland-Belarus-Ukraine.

Thus, public diplomacy is an integral auxiliary tool for the implementation of the foreign policy of both Ukraine and Belarus. The development of good-neighbourly relations by deepening cultural ties at the level of civil society certainly needs to be paid more attention, taking into account the existing security challenges in the region. In the near future, public diplomacy, as a tool, should become a locomotive in solving problematic aspects of relations between the two states, and the improvement of its mechanisms on the example of Ukraine-Belarus relations should become the subject of study of political science.

Key words: public diplomacy, Ukrainian-Belarusian relations, strategic partnership, foreign policy. 